\title{
2.サリドマイド等のリスク最小化策改訂の 評価ポイント
}

\author{
佐藤 嗣道 \\ 東京理科大学薬学部薬学科／公益財団法人いしずえ
}

\begin{abstract}
〈抄録>サリドマイドおよびその誘導体であるレナリドミド，ポマリドミドは強い催奇形 性をもつことから，これらの薬剤の「胎坚曝露を 1 例も起こさない」ことを目的に,「サリ ドマイド製剤安全管理手順 $\left(\mathrm{TERMS} \mathrm{S}^{\circledR}\right) 」$ 」おび「レブラミド®ポマリスト®適正管理手順 $\left(\right.$ RevMate $\left.^{\mathbb{R}}\right) 」$ が運用されている。本稿では，これらの管理手順の大幅な改訂（2016 年 4 月 1 日実施）に伴うリスク最小化策の評価ポイントについて記した，今回の改訂では，中 央での一元的管理が緩和され，患者，医師，薬剤師の遵守状況に関する製薬企業の管理セ ンターによる確認は事後的となり，医師・薬剤師による確認の重要性が増した。患者が妊 娠回避等の行動を振り返り記入する「定期確認票」は, 従来のように患者が管理センター に郵送するのではなく, 受診の際に医師に渡し, 記入内容を医師が確認することになった. また，家庭内の薬剤管理責任者の設置についても，患者自身による管理が可能な場合は不 要とした。これらの改訂は患者会の要望に沿うものではあるが, 改訂に伴い各医療機関に 扔ける管理手順の実施体制が適切に構築されたか，医師・薬剤師による不遵守・冕脱が増 加していないかを評価する必要がある。加えて,「定期確認票」への記入場所が自宅ではな く病院となるケースが増えると思われることから，それが患者の妊娠回避に関する意識と 行動に影響を与えたかを評価できるとよい，また，家庭内に薬剤管理責任者を置かない場 合に、リスクの認識と適切な行動に関する理解がパートナー/家族と共有されるかも評価 のポイントとなる，改訂に伴う影響については，「TERMS 第三者評価委員会」および 「RevMate 第三者評価委員会」による患者，医師，薬剂師を対象とする調査が行われてお り，近く結果がまとまる予定である。

(薬剤疫学 $2017 ； 22(1): 9-18)$ キーワード：サリドマイド，レナリドミド，ポマリドミド，催奇形性，リスク最小化策
\end{abstract}

\section{1.はじめに}

サリドマイド製剤安全管理手順（Thalidomide Education and Risk Management System: $\left.\mathrm{TERMS}^{\circledR}\right)^{1)}$ と, レナリドミドおよびポマリドミド のリスク最小化策であるレブラミド®・ポマリス 卜®適正管理手順 $\left(\text { RevMate }^{\circledR}\right)^{2)}$ の大幅な改訂が, 2015 年 9 月に厚生労働省の薬事・食品衛生審議会 医薬品等安全対策部会安全対策調査会で決定さ
れ²，2016 年 4 月から施行された。改訂前の $\mathrm{TERMS}^{\circledR}$ および RevMate ${ }^{\circledR}$ は，製薬企業の管理セ ンターが，薬剤の配布を中央で一元的に管理し， 当該薬剤を処方する病院の医師と責任薬剤師, お よび患者の遵守状況を確認した後に，薬を患者に 渡すことを許可するシステムであった（図 1)。ま た，家庭内の「薬剤管理責任者」の設置と氏名の 登録が必要であった。しかし, 今回の改訂により，

連絡先： $\overline{7} 278-8510$ 千葉県野田市山崎 2641 東京理科大学薬学部薬学科 佐藤嗣道

E-mail : tsugusato@rs.tus.ac.jp 


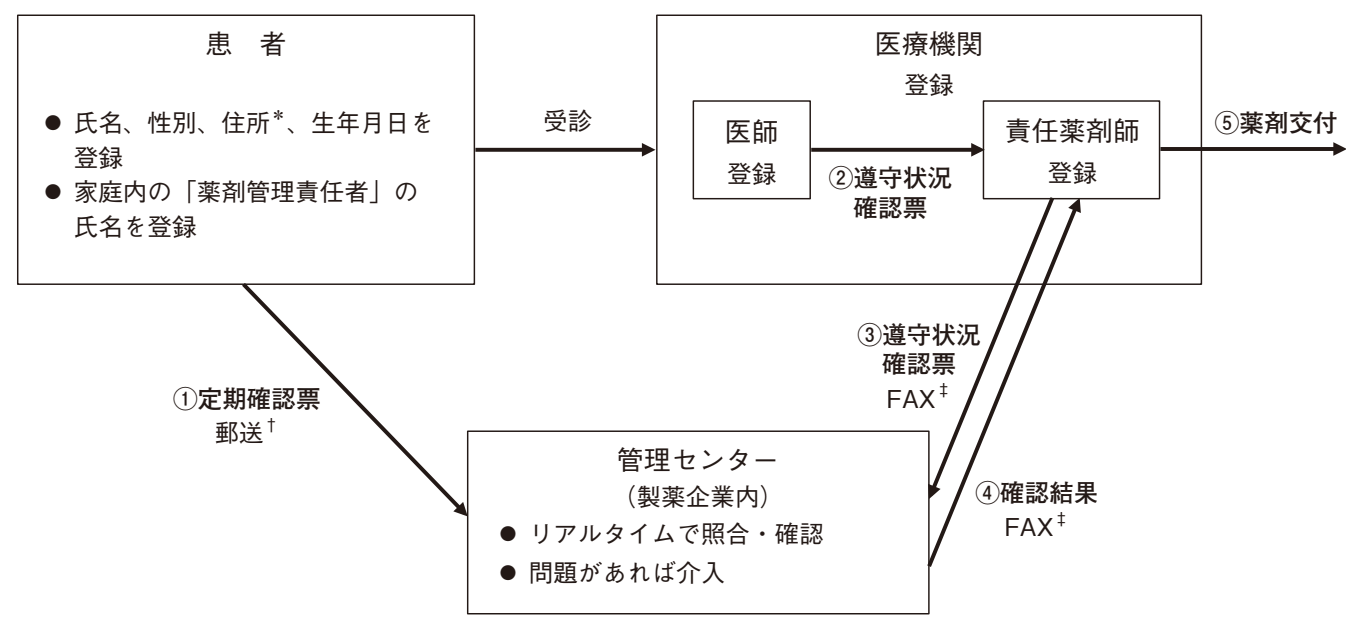

図 1 改訂前（2016 年 3 月以前）の TERMS ${ }^{\circledR}$

(1) および (3)により問題がないことを管理センターが確認し，(4)責任薬剤師が確認結果を受け取ってから，(5) 薬剤を交付する。

*RevMate ${ }^{\circledR}$ では住所の登録は不要.

“提出の頻度 : 妊娠可能な女性患者は 1 カ月ごと．男性患者は 2 カ月ごと．妊娠の可能性/機会のない女性患者 は 6 カ月ごと.

${ }^{\ddagger}$ RevMate ${ }^{\circledR}$ ではハンデイ端末を利用して通信. 入力内容をハンデイ端末自身が碓認し通信前に結果を表示.

表 1 患者が記入する定期確認票の質問項目 $\left(T E R M S^{\circledR}\right)$ ：妊娠可能な女性患者

\begin{tabular}{|c|c|c|}
\hline (1) 本剂の保管・管理を適正に行いましたか. & $\square は い$ & $\square$ ロいえ \\
\hline $\begin{array}{l}\text { (2) 性交渉がなかったか, または規定された避妊方法を男性パート } \\
\text { ナーとともに行いましたか*. } \\
\text { （性交渉なし，または避妊方法を行った場合は「はい」に記入し } \\
\text { てください) }\end{array}$ & $\square は い$ & ロいいえ \\
\hline (3) 本剂を他人と共有, 他人に譲渡あるいは廃棄しましたか. & $\square は い$ & $\square$ ロいえ \\
\hline (4) 本剤を紛失しましたか. & $\square は$ 古 & $\square$ ロいえ \\
\hline
\end{tabular}

*男性患者の場合は「性交渉がなかったか，または規定された避妊方法を行いましたか」. 妊娠の可能性/機会がないと判断された患者については, この質問項目はない.

患者が妊娠回避等の行動を振り返り記入する「定 期確認票」(表 1) の内容確認は受診時に医師が行 い, それに加えて医師と薬剤師が各々の遵守状況 を確認すれば患者への薬剤交付が可能となり，製 薬企業の管理センターによる確認は事後的となっ た（図 2)。また，患者氏名の登録が廃止され，患 者登録番号, リスク区分, 生年月日のみの登録と なった，家庭内の薬剤管理責任者の設置について
も, 患者自身による管理が可能な場合は不要とし， 設置の有無のみの登録（氏名は登録不要）となっ た。

今回の改訂は TERMS ${ }^{\circledR}$ および RevMate ${ }^{\circledR}$ 運用 開始以来の大改訂と言ってよいが，この背景には 骨髄腫の患者会の要望がある ${ }^{4}$ ．患者にとって は, (1) 氏名が企業の管理センターに登録されなく なったこと，および (2) 妊娠回避等に関する定期 
薬剤疫学 Jpn J Pharmacoepidemiol, 22(1) June 2017 : 11

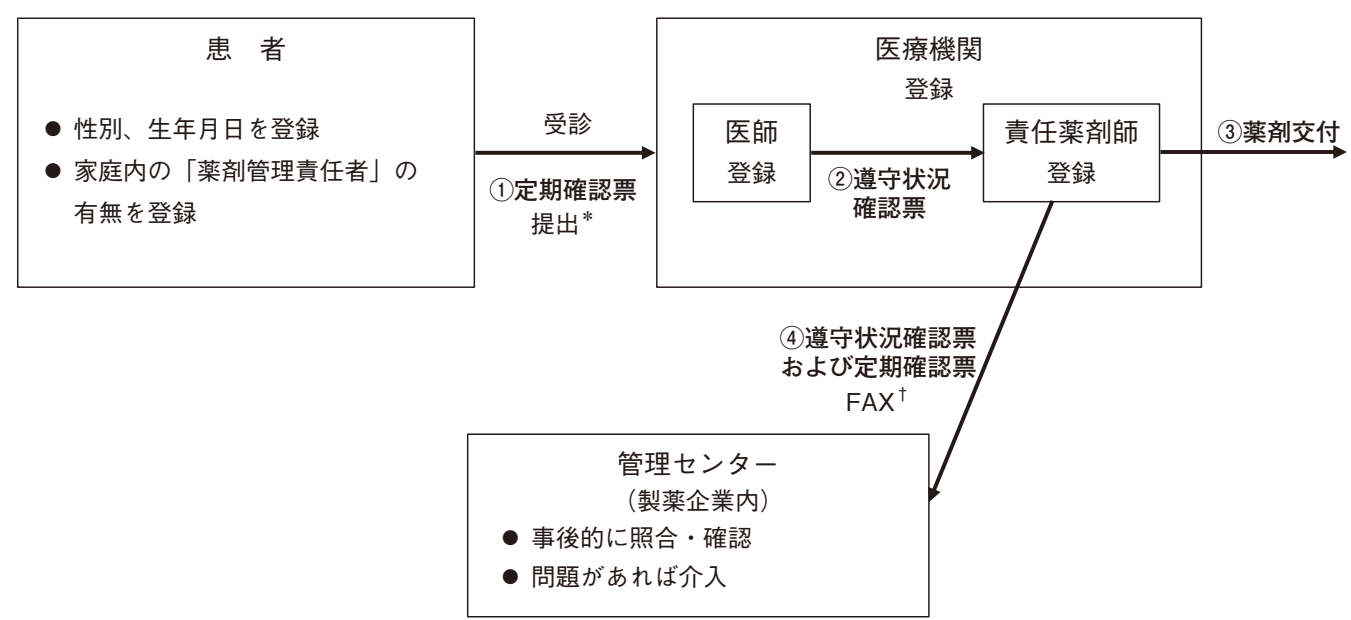

図 2 改訂後（2016 年 4 月以降）の TERMS ${ }^{\circledR}$

(1) 定期確認票の内容を医師が確認し，(2)により問題がないことを責任薬剤師が確認し (3) 薬剂を交付する. (4) その後管理センターに送信.

*提出の頻度：妊娠可能な女性患者は 1 カ月ごと，男性患者は 2 カ月ごと，妊娠の可能性/機会のない女性患者 は 6 カ月ごと.

${ }^{\dagger} \operatorname{RevMate}^{\circledR}$ ではハンデイ端末を利用して通信．入力内容をハンデイ端末自身が確認し通信前に結果を表示.

確認票を，企業の管理センターに直接郵送するの ではなく，受診の際に医師に手渡すようになった ことが大きな変更点である。この改訂により，管 理手順に対する患者の不満は緩和されたかを評価 するとともに，医療現場での負担が増していない か, および胎児曝露のリスクが高まることがない かについても評価することが必要であろう.

筆者は, これらのリスク管理システムの運用に ついて第三者の立場から評価する, TERMS ${ }^{\circledR} の$ 「第三者評価機関」および「RevMate 第三者評価 委員会」(以後, 便宜上, 「TERMS 第三者評価委 員会」,「RevMate 第三者評価委員会」と記す）に 委員として参加してきた。本稿では, サリドマイ ド,レナリドミドおよびポマリドミド（以下，「サ リドマイド等」) の催奇形性の特徴について改め

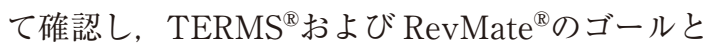
評価ポイントについて整理したうえで，今回の管 理手順改訂の評価に関して考慮すべきポイントと 改訂後に発生した問題について述べる.

\section{2. サリドマイド等の催奇形性}

サリドマイドの催奇形性は, 1950 年代末から
60 年代初めの世界的なサリドマイド禍の発生に より明らかとなった. Nowack ${ }^{5)}$ は, ドイッでの詳 細な調査結果に基づき, サリドマイドについての 過敏期は最終月経後 34 日から 50 日であると報告 している. Lenz $z^{6)}$ は, ドイッでの多数の症例に基 づき, 過敏期にサリドマイド服用を証拠付ける記 録があるにもかかわらず健常児を産んだ例は 1 例 もなかったことを述べている。また，Nowack ${ }^{5}$ は，妊娠中のサリドマイド服用歴が明らかで奇形 の子供を出産した母親 82 例のうち, 7 例は 1 錠を 1 回服用しただけであることを報告している。 日 本でも，聞き取り調査を行った 30 例中 1 例が 1 回のみの服用であったことが報告されている7). すなわち, サリドマイドは, 過敏期に 1 回 1 錠服 用するだけで確実に奇形を起こす, 極めて催奇形 性の強い薬物であり, 催奇形性を有する他の薬に 比べ，より厳格なリスク管理が必要な薬であると いえよう。

レナリドミドおよびポマリドミドは, サリドマ イドの誘導体である.レナリドミドについては, ラットおよびウサギの実験で催奇形性が認められ なかったことから, 開発当初は催奇形性のない薬 
として期待された ${ }^{8)}$. しかし，カニクイザルの実

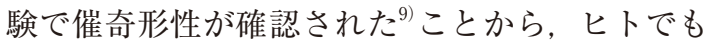
サリドマイドと同様の催奇形性をもつ可能性が十 分に考えられる。ポマリドミドは，ラットとウサ ギで催奇形性が認められている ${ }^{10)}$ 。このことか ら,レナリドミドおよびポマリドミドについても， サリドマイドと同様のリスク管理が必要とされ た。

\section{TERMS $^{\circledR}$ ・ RevMate ${ }^{\circledR}$ のゴールと評価ポイント} 3.1 TERMS $^{\circledR} \cdot$ RevMate $^{\circledR}$ のゴール

TERMS $^{\circledR}$ および RevMate ${ }^{\circledR}$ 目的は, サリドマ イド等の「胎児への曝露を防止すること」である. $\mathrm{TERMS}^{\circledR}$ および RevMate ${ }^{\circledR} に は$ 具体的数值目標は 明示されていないが，厚生労働省の「サリドマイ ド被害の再発防止のための安全管理に関する検討 会」（2008）において，「胎児曝露等による健康被 害を二度と起こさないことを目標」とすることが 確認されており ${ }^{11)}$, 胎児曝露を 1 例も起こさない ことが両管理手順のゴールである。この検討会で は，同時に「患者が治療を受ける権利や人権にも 配慮し, 実効性のある安全管理を実行する」こと

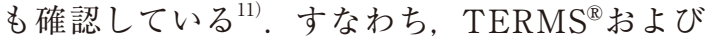
$\operatorname{RevMate}^{\circledR} に$ に, 当該薬剤の胎児曝露を 1 例も起 こさないことを目標に, この目標達成に必要な要 素を満たしたうえで, 患者の薬物治療へのアクセ スをできる限り阻害せず，医療従事者・患者の負 担が少ない, 実効性のあるプログラムであること が求められている.

\section{2 胎児曝露防止のために必要なこと}

サリドマイド等の胎児曝露を防止するために は, 患者とパートナーが薬剤の危険性を認識して 適切な行動を取ることが必要である。 TERMS ${ }^{\circledR}$ および RevMate ${ }^{\circledR}$ は，妊娠可能な女性患者と男性 パートナーに対して妊娠回避の徹底を求めてお

り, 当該薬剤の服用中は性交涉を行わない, また は男女合わせて 2 種類以上の避妊法（女性はピル など，男性はコンドーム）を用いるべきことを規 定している。また，男性が服用する場合にも，コ ンドームを用いて避妊すべきことを規定してい る。これは，サリドマイド等が男性（ヒト）の精
液に移行することが確認されているためであ る ${ }^{12), 13)}$.サリドマイドについては，雄ウサギの精 液のみならず精子にも移行すること，また雄ウサ ギにサリドマイドを長期間投与すると，その雄と 交配したサリドマイドを投与されていない雌から 生まれた仔に先天的な異常が認められたことが報 告されている ${ }^{14)}$ 。サリドマイド等による催奇形性

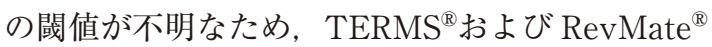
は，当該薬剤を服用した男性患者に対して，妊婦 との性交涉を禁止するとともに，妊娠可能な女性 との性交渉においてはコンドームを用いた避妊を 求めている ${ }^{1,2)}$. 胎児曝露を防止するには，精子 ・ 精液を女性パートナーに触れさせないことが必要 である。

サリドマイド等の妊婦への投与は禁忌であり,

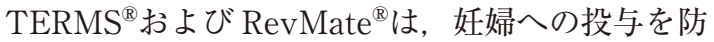
止するため, 妊娠可能な女性患者には服用開始 4 週間前から妊娠検査を行うべきことを規定してい $3^{1), 2)}$. 服用開始後も月 1 回の妊娠検査を義務付 けているが, 服用開始後の妊娠検査については胎 児曝露の発見には役立つが防止には役立たないこ とに留意すべきである，通常の妊娠検査薬で陽性 反応がほほ確実に検出できるのは, 妊娠 3 週間後 以降であり, これは最終月経後 35 日以降に相当 する。したがって，サリドマイド服用中の月 1 回 の妊娠検查が陽性になった場合には，すでに過敏 期に入っているか，その少し前の時期（過敏期の 前の曝露は流産となる可能性が示唆されている) であり，胎児（胎芽）はすでに何らかの影響を受 けていると思われる。

\subsection{TERMS $^{\circledR} \cdot$ RevMate $^{\circledR}$ における各ツールの意義}

$\mathrm{TERMS}^{\circledR}$ および RevMate ${ }^{\circledR}$ は, 厚生労働省の「医 薬品リスク管理計画指針」星ににおいて, 「6.2.3 医 薬品の使用条件の設定」に該当する。この指針で は，使用条件の例として「専門的知識・経験のあ る医師による使用の確保」,「医薬品の使用管理体 制の確保」,「投与対象患者の慎重な選定」,「投与 に際しての患者への説明と理解の実施」, および 「特定の検査等の実施」が挙げられているが,

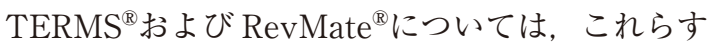
べてに該当する使用条件が定められている。この 
中でとくに重要なのが「投与に際しての患者への 説明と理解の実施」と「医薬品の使用管理体制の 確保」である。言い換えれば,「『教育』と『遵守 すべき事項』の確実な実施とその確認」がサリド マイド等のリスク管理の鍵となるコンセプトであ る. そのためには, 「医薬品の流通・処方・調剂・ 使用に関する一元的管理」とその前提としての医 師・薬剤師および患者の登録等が必要となる.

教育については, 製薬企業による医療従事者向 けの教育と医療従事者による患者向けの教育の実 施が義務付けられており，それを満たすことを条 件に医師・薬片師および患者が登録される。とく に患者向けの教育資材は, 患者が薬の危険性を認 識し妊娠回避等の適切な行動を取るために重要な ッールである，遵守事項の確認については, 患者 が確認・記入する「定期確認票」, および医師・薬 剤師が確認・記入する「遵守状況確認票」がツー ルとして用いられている。「定期確認票」の意義 は, 単なる知識のリマインドではなく, 患者自 身が自らの行動を定期的に振り返って確認し報

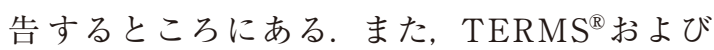

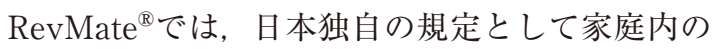
「薬荗管理責任者」の設置が定められている ${ }^{1) 22}$. これは家庭内での薬剤の管理にとどまらず，催奇 形性のリスクに関する認識と患者の適切な行動に ついての理解を患者とパートナー/家族が共有す ることに本来の意義があると考えられる.

\subsection{TERMS $^{\circledR} \cdot$ RevMate $^{\circledR}$ の評価ポイント}

リスク最小化活動の評価においては, 目標 (ゴー ル）達成に関する評価と, ッール（リスク管理プ ログラムおよび資材）の評価を区別することが重

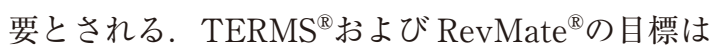
胎児曝露を 1 例も起こさないことである．妊娠可 能な女性患者については妊娠中の当該薬剤の服用 および当該薬剤服用中の妊娠が 1 例もないことが 目標達成に関する指標となるであろう。この指標 は, 服用開始前および開始後の毎月の妊娠検査に より確認が可能である。幸いなことに, 女性患

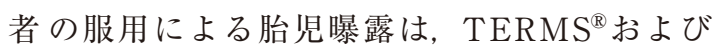
RevMate $^{\circledR}$ ではこれまで 1 例も報告されていな w.
一方, 男性患者については, 妊婦との性交涉 (禁 止事項)，および女性パートナーの妊娠が 1 件も

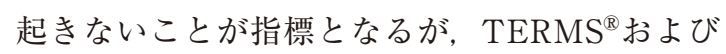
RevMate ${ }^{\circledR} に は$, この指標に関する明確な調查項 目は存在しない. 患者自身が記入する定期確認票 （男性患者は 2 力月に 1 回）に，「性交渉がなかっ たか，または規定された避妊方法を行いました か?」という質問項目があり，妊娠回避が適切に 行われなかった事例を確認できる可能性がある が, これだけでは目標達成を確認する指標とはな らない，TERMS 第三者評価委員会による患者へ の電話インタビュー（6 カ月ごと）において,「避 妊に失敗したかもしれないと思ったことがありま すか? 」との質問があり, そこでも妊娠事例が把握 される可能性があるが, 電話インタビューへの協 力率は高いとは言えず $\left(2009\right.$ 2011 年で 57\% ${ }^{16)}$, 確実な把握は不可能である。今のところ, 男性患 者の妊婦との性交涉や女性パートナーの妊娠が $\mathrm{TERMS}^{\circledR}$ および RevMate ${ }^{\circledR} て ゙$ 報告された例はない が，今後は男性患者が服用した場合の目標達成に 関する評価を可能にすることが課題であろう.

ちなみに，米国でのサリドマイドのリスク管理 プログラム (System for Thalidomide Education and Prescribing Safety : S.T.E.P.S. $\left.{ }^{\circledR}\right)$ では, 2004 年までにサリドマイド服用中の女性患者の妊娠 (自然流産) が妊娠検査により 1 例確認され ${ }^{17)}$, 男 性患者のパートナーの妊娠については第三者評価 によって 1 例が確認されている ${ }^{18)}$ 。また, レナリ ドミドについては, その審査報告書によれば, 海 外では 2010 年 6 月までに女性患者の妊娠 7 例 (人 工妊娠中絶 5 例, 自然流産 1 例, 転帰不明 1 例), 男性患者の妊婦との性交涉 1 例（転㷌不明），およ び男性患者のパートナーの妊娠 6 例（正常出産 1 例, 人工妊娠中絶 1 例, 自然流産 1 例, 転帰不明 3 例）が報告されている ${ }^{19,20)}$.

ツールの評価については, ツールが規定された とおりに稼動しているかを評価するとともに, 各々のツールが目標（ゴール）達成にどの程度役 立っているかを評価することが必要である，前者

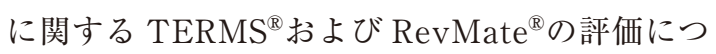
いては, 医師, 薬片師, 患者が規定された手順を 
どの程度遵守したかが指標となる，患者が記入す る「定期確認票」と医師・薬剂師が記入する「遵 守状況確認票」により製薬企業が遵守状況を把握 し，問題があれば介入することになっている.

患者による定期確認票の提出状況については,

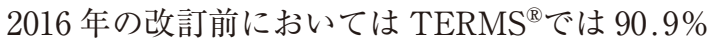
(3607/3968), RevMate ${ }^{\circledR}$ では 85.3\%（7913/9280） であることが報告されている ${ }^{21)}$. 患者の遵守状況

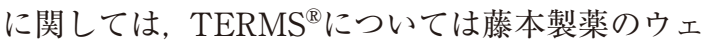
ブサイト上で逸脱事例が公表されている ${ }^{22)}$. RevMate ${ }^{\circledR} に お け る$ 冕脱事例については, 一部 がセルジーン社のウェブサイト上 ${ }^{23)}$ で，また RevMate 第三者評価委員会の第 16 回 (2014 年 11 月）以降の議事録 ${ }^{24)}$ において公表されている. 患者・家族による逸脱事例の多くは, 家庭での薬 剂の紛失および残薬の未返却であり，妊娠回避に 関する患者の不遵守が問題となった事例は $\mathrm{TERMS}^{\circledR}$ では 2009 年から 2016 年までに 1 件 (RevMate ${ }^{\circledR}$ では 2014 年 10 月から 2016 年までで は 0 件）であった。一方, 医師・薬剤師の遵守状 況については，遵守状況確認票を記入せず，また はその内容を製薬企業の管理センターへ送信せず に薬剤を交付した例（送信の失念および薬剤交付 後の送信を含む）が 2016 年までに多数報告され た．また，病棟における入院患者への誤投与と薬 剂紛失の事例が報告されている。こうした事例 は, 医療安全におけるヒヤリ・ハットに相当し, 放置すれば重大な事故につながる恐れがあること から, その都度, 各第三者評価委員会から製薬企 業に対して医療機関への再教育を含む対策を求め ている.

個々のツールの目標達成への寄与を評価する ためには，それがあった場合となかった場合で 結果を比較するのがもっともストレートな方 法である。薬の発売当初から TERMS ${ }^{\circledR}$ おび RevMate ${ }^{\circledR}$ が構築されている状況においては, こ の比較は通常は不可能であるが, 管理手順の改訂 に伴って変更または廃止されたツールがあること から, 改訂前後の比較によりその評価が可能かも しれない. しかし, 改訂後に胎児曝露が発生した 場合を除いては，その評価には限界がある。すな
わち, ッールの変更・廃止に伴い, 胎児曝露の潜 在的リスクに影響を与えたか否かの評価は困難だ からである、ただし, 改訂前後における不遵守や ヒヤリ・ハットの事例の比較から問題点を抽出す ることは可能であろう。

また, 医師, 薬剤師, 患者を対象とした意識調 査の結果から, ツールの目標達成への寄与に関す る示唆を得ることができる. TERMS 第三者評価 委員会では, 患者を対象とする電話インタビュー を，サリドマイド剤の使用開始直後と以後 6 力月 ごとに実施し, 患者の理解度と意識を継続的に調 査している。 また, 医師, 薬荗師を対象とする自 記式質問票による意識調査を年 1 回行っている. RevMate 第三者評価委員会では, レナリドミド の発売から 1 年が経過した 2011 年に医師, 薬剤 師，患者を対象とする自記式質問票による意識調 査を行った。

ツールの評価においては, 患者の薬牏へのアク セスを不必要に阻害していないか検討するととも に, 患者, 医師, 薬剤師の負担についても検討す ることが重要である. 米国 Food and Drug Administration (FDA) によるリスク最小化活動計 画に関するガイダンス（RiskMAP ガイダンス， $2005)^{25)}$ では,「医師・薬片師・患者の負担が最小 なツールを選択すること」, および「リスク最小化 の条件が満たされるなら, 可能な限りもっとも幅 広い薬へのアクセスを保障すること」が推奨され

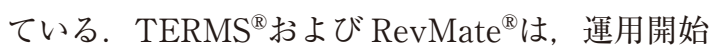
以来，第三者評価委員会による調査結果と提言も 参考に，この観点での見直しが複数回にわたって 行われた。 その結果, 煩雑さをできる限り取り除 き,より現実に即したリスク管理システムへの改 訂が行われ, 病院での患者の待ち時間の短縮や負 担軽減などの改善が図られてきた。

\section{4. 改訂に関する評価ポイント}

今回の改訂におけるもっとも大きな変更点は, 中央での一元的管理の緩和である. 従来の管理手 順では, 患者の遵守状況と医師・薬剤師の遵守状 況を製薬企業の管理センターが確認した後に薬剤 が交付されていたが，改訂後は管理センターによ 
表 2 第三者評価委員会の調査における追加の質問項目（患者調査）

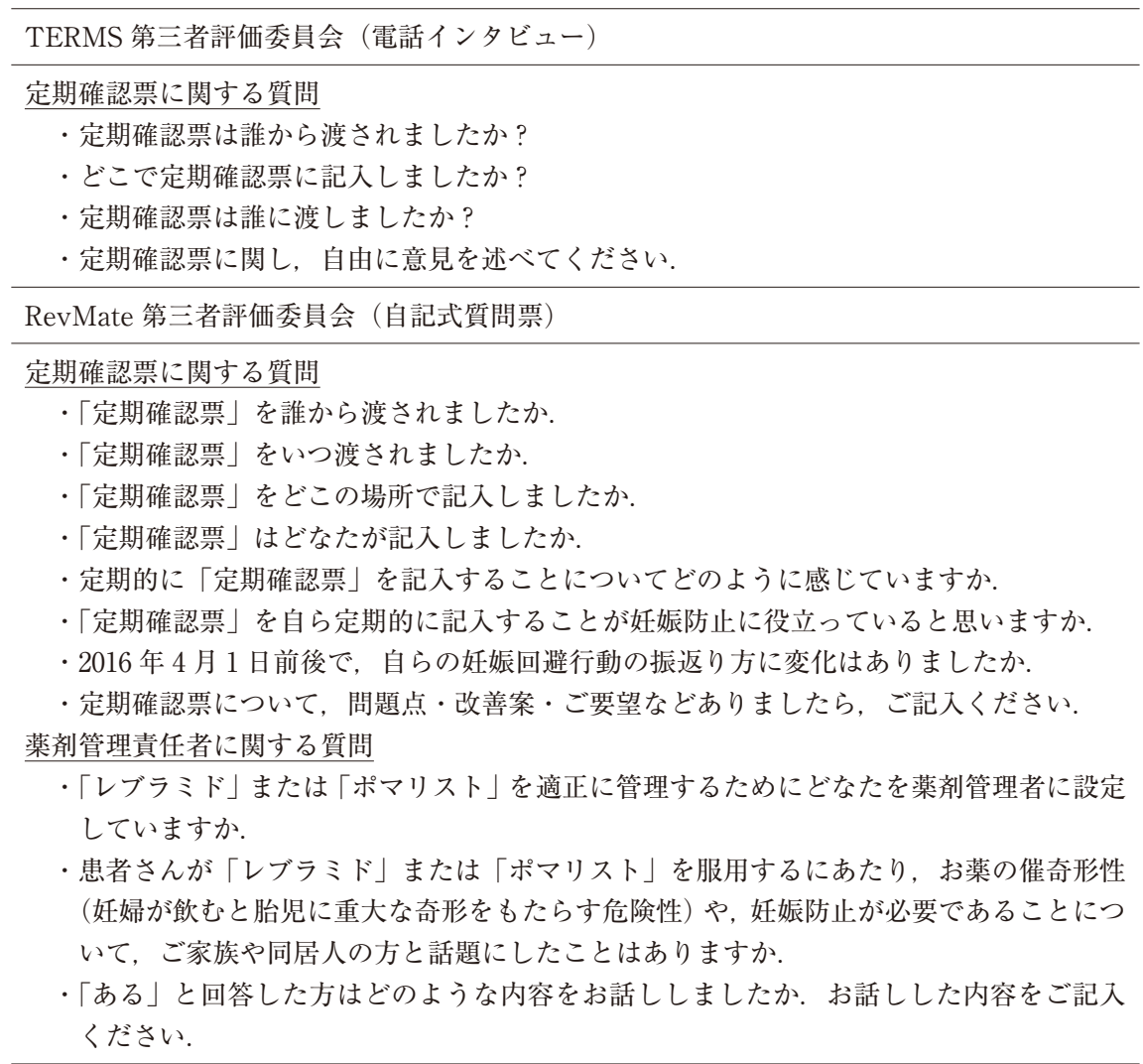

医師・薬剤師を対象とする調査においても，主に定期確認票に関する質問と薬剂管理責任 者に関する質問が追加された。

る確認は事後的となり, 医師・薬剤師による確認 の重要性が増した。各医療機関における管理手順 の実施体制が適切に構築されたか，医師・薬剤師 による不遵守・逸脱が増加していないか, といっ た点を評価する必要があると思われる.

もう 1 つの重要な変更点は, 患者が「定期確認 票」を管理センターに郵送せず，受診の際に医師 に渡すことになったことである。改訂前において は,「定期確認票」を受け取った患者は, 通常はそ れに自宅で記入していたと思われる. しかし, 改 訂後は来院の際に患者が「定期確認票」を受け取 り, 病院の待合室等でそれに記入し, その場で医 師に渡すことが可能となった。「定期確認票」を 薬剂師等から事前に受け取り, 次回の来院までに 自宅で記入して持参する手順も取りうるが，どち
らの手順にするかは各医療機関に任されることと なった．筆者は，自らの妊娠回避という極めてプ ライベートな行動を振り返って記入する場として 病院はふさわしくなく, 日常生活の場である自宅 で記入することが望ましいと考えている。「定期 確認票」への記入環境の変化が, 患者の妊娠回避 に関する意識と行動に影響を与えたかを検討でき るとよいと思われた，また，この手順変更が医療 現場の混乱と負担増を招き, 医療機関における不 遵守事例が増加することが懸念された。 とくに, 改訂後は患者から「定期確認票」を医師が受け取 り確認することになり，医師の負担増大が予想さ れた。

家庭内の「薬剂管理責任者」の設置を患者自身 による薬剤管理が可能な場合は不要としたことに 
ついては,リスクに関する認識と適切な行動につ いての理解を患者とパートナー/家族が共有する ことに影響を与えるか, またそれが妊娠回避行動/ 薬剂管理に影響を与えるかが評価のポイントとな る.

以上の点を踏まえて，各第三者評価委員会にお ける調査において, 従来の質問項目に加えて,「定 期確認票」の受け渡しと記入の実際,「定期確認票」 に対する意識，および「薬剤管理責任者」に関す る質問項目が設けられた（表 2)。TERMS 第三者 評価委員会においては，2016 年 12 月から患者へ の電話インタビューで追加の質問が開始され, 医 師・薬剤師に対しては追加の質問項目を含む調査 が 2016 年 9 月に実施された. RevMate 第三者評 価委員会では, 2011 年の調査項目に改訂に伴う質 問項目を加えた調査が, 患者, 医師, 薬剤師を対 象に 2016 年 11 月から 2017 年 1 月にかけて実施 された。これらの調査結果は近くまとまり，いず れ公表されるものと思われる.

\section{5. 改訂に伴い発生した問題}

\section{1 医療現場における負担の増大}

今回の改訂に伴い,「遵守状況確認票」に加えて 「定期確認票」の原本を病院で保管することとなっ たが，スペースの関係上，保管が難しい施設が少 なからずあることが明らかになった ${ }^{26)}$. 今後は保 管場所に困っている施設に対し, 書類の電子的な 保管を可能とすることが検討されている.

\section{2 製薬企業による RevMate ${ }^{\circledR}$ 違反}

上記に加え, 製薬企業自身による規定違反 という重大な問題が発生した。 2016 年 5 月の RevMate 第三者評価委員会において，「定期確認 票」の記入内容が製薬企業に送信されていないこ

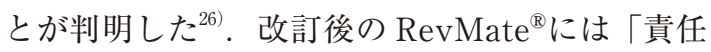
薬剂師は, ハンディ端末を用いて遵守状況確認の 内容を RevMate センターにデータ送信する（定 期的な記入のタイミングでは定期確認票の内容も 合わせてデータ送信する).」と明記されている. したがって，製薬企業は改訂に伴いハンディ端末 の仕様を変更しなければならなったが，それがな されていなかったのである，第三者評価委員会
は, 2016 年 8 月に現状では RevMate ${ }^{\circledR} に$ 違反して いる状況であることを確認し早急な対応を求めた ところ, 製薬企業からハンデイ端末の仕様を変更 する対応案が提案されたことから，そのように対 応することを企業に求めた ${ }^{27)}$. その結果, 2016 年 11 月に応急措置的な対応が行われ ${ }^{28)}, 2017$ 年 2 月にハンディ端末の改修が完了した ${ }^{29)}$.

\section{6. おわりに}

今回の改訂では, 製薬企業自身が改訂に伴って なすべき事柄を理解していないことによる問題が 発生した。一元的管理の緩和は, 責任の主体を曖 昧にすることにつながるなど，リスク管理システ ムの基本的なコンセプトに関わる問題をはらんで

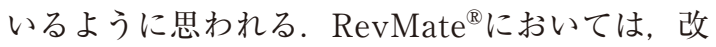
訂後に入院患者に対する誤投与が相次ぎ, 2017 年 1 月に入院患者の誤投与を防止するための管理手 順の再改訂が行われた ${ }^{30)}$. 米国での S.T.E.P.S. ${ }^{\circledR}$ 構 築にFDAの立場から関与した $\mathrm{Uhl}^{17)}$ は「患者や 医療関係者の全てが胎児への危険性を理解し，リ スクを小さくするよう動かなければ, 妊娠の防止 という目標を達成することはできない」と述べて いる．わが国で胎児曝露を 1 例も起こさないとい うゴールを今後も達成し続けるためには, 行政, 製薬企業，医療従事者および患者・関係者による 絶え間ない注意と努力が求められる.

\section{文献}

1）藤本製薬株式会社．サリドマイド製剤安全管理手順 サレドカプセル TERMS ${ }^{\circledR}$ (Thalidomide Education and Risk Management System)。2015 年 10 月 7 日第 5 版 改訂（2016 年 4 月 1 日実施）。 [http:// www.fujimoto-pharm.co.jp/jp/iyakuhin/thalido/ pdf/TERMS-5.pdf (accessed 2017-5-4)]

2）セルジーン株式会社. RevMate ${ }^{\circledR}($ レブラミド®・゚ マリス卜®適正管理手順)。Ver. 5.2 (2017 年 3 月改 訂). [http://www.revmate-japan.jp/ver5/profes sional/pdf/RevMate_Management_v5_2.pdf（accessed 2017-5-4) ]

3）厚生労働省医薬食品局安全対策課. 2015 年 9 月 2 日第 2 回薬事・食品衛生審議会医薬品等安全対策部 会安全対策調查会 議事録. [http://www.mhlw.go. jp/stf/shingi2/0000100166.html (accessed 2017-54)] 
4）日本骨髄腫患者の会. サリドマイド製剤安全管理手 順「TERMS」およびレブラミド適正管理手順 $\lceil$ RevMate」に関する要望書. [平成 26 年度第 10 回 薬事・食品衛生審議会医薬品等安全対策部会安全対 策調查会 資料]. [http://www.mhlw.go.jp/stf/ shingi2/0000072902.html（accessed 2017-5-4) ]

5) Nowack E. Die sensible Phase bei der ThalidomidEmbryopathie. Humangenetik $1965 ; 1$ (6) : 516-36. (in German)

6) Lenz W. Das Thalidomid-Syndrom. Fortschr Med $1963 ; 81:$ 148-54. (in German)

7) Kida M, Lenz W. Die Thalidomid embryopathie in Japan. Arch Kinderheilkd 1968; 177 (3) : 244-59. (in German)

8) Christian MS, Laskin OL, Sharper V, et al. Evaluation of the developmental toxicity of lenalidomide in rabbits. Birth Defects Res B Dev Reprod Toxicol 2007 ; 80 (3) : 188-207.

9）七ルジーン株式会社. 医薬品インタビューフォーム レブラミド®カプセル 2017 年 1 月改訂 (第 11 版).

10）セルジーン株式会社. 医薬品インタビューフォーム ポマリスト®カプセル 2015 年 8 月改訂 (第 3 版).

11）厚生労働省. サリドマイド製剤の安全管理に関する 確認事項について. [平成 20 年度第 2 回薬事・食品 衛生審議会医薬品等安全対策部会 資料]。 [http:// www. mhlw. go. jp/shin gi/2008/09/s0930-6. html (accessed 2017-5-4) ]

12) Teo SK, Harden JL, Burke AB, et al. Thalidomide is distributed into human semen after oral dosing. Drug Metab Dispos 2001 ; 29 (10) : 1355-7.

13）藤本製薬株式会社. 医薬品インタビューフォーム サレド ${ }^{\circledR}$ カプセル 2014 年 7 月改訂 (改訂第 8 版).

14) Lutwak-Mann C, Schmid K, Keberle H. Thalidomide in rabbit semen. Nature $1967 ; 214$ (5092) : 1018-20.

15）厚生労働省. 医薬品リスク管理計画指針について. 薬食安発 0411 第 1 号 薬食審査発 0411 第 2 号 平成 24 年 4 月 11 日. [https://www.pmda.go.jp/files/ 000145482.pdf (accessed 2017-5-4) ]

16）TERMS 第三者評価委員会. TERMS 第三者評価委 員会により実施された, 患者・医療関係者アンケー 卜結果. [平成 23 年度第 10 回薬事. 食品衛生審議 会医薬品等安全対策部会安全対策調査会 資料]. [http://www.mhlw.go.jp/stf/shingi/2r985200000 256oh.html (accessed 2017-5-4)]

17) Uhl K, Cox E, Rogan R, et al. Thalidomide use in the US : experience with pregnancy testing in the S.T.E. P.S. ${ }^{\circledR}$ programme. Drug Saf $2006 ; 29$ (4) : 321-9.
薬剂疫学 Jpn J Pharmacoepidemiol, 22(1) June 2017 : 17

18) Bennekom CMV, Mitchell AA. The voluntary thalidomide survey. Pharmacoepidemiol Drug Saf $2003 ; 12$ (Supple 1) : S131.

19) 医薬品医療機器総合機構。審査報告書 (2010 年 6 月 25 日).

20) 医薬品医療機器総合機構。審査報告書 (2010 年 8 月 20 日).

21）厚生労働省医薬食品局安全対策課. TERMS 及び RevMateに拈ける定期確認調査票及び遵守状況確 認票の回収状況について. [第 5 回サリドマイド及 びレナリドミドの安全管理に関する検討会 $(2014$ 年 7 月 10 日開催) 資料 3]. [http://www.mhlw.go. jp/stf/shingi/0000050983.html（accessed 2017-54)]

22）藤本製薬株式会社. TERMS ${ }^{\mathbb{P}}$ について. [http:// www.fujimoto-pharm.co.jp/jp/iyakuhin/thalido/in dex.php (accessed 2017-5-4) ]

23）セルジーン株式会社. RevMate 医療関係者向け. 誤投与 - 逸脱事例. [http://www.revmate-japan. jp/ver5/professional/errorcase/index01.html (ac cessed 2017-5-4) ]

24）RevMate（レブメイト）第三者評価委員会. 開催状 況/議事録. [http://www.rm-3prc.jp/wordpress/ board (accessed 2017-5-4) ]

25) U.S. Department of Health and Human Services, Food and Drug Administration. Guidance for Industry Development and Use of Risk Minimization Action Plans. 2005. [https://www. fda. gov/ downloads/regulatoryinformation/guidances/ ucm126830.pdf (accessed 2017-5-4)]

26） RevMate 第三者評価委員会. 第 22 回議事録 $(2016$ 年 5 月 25 日開催)。 [http://www.rm-3prc.jp/ wordpress/board (accessed 2017-5-4) ]

27） RevMate 第三者評価委員会. 第 23 回議事録 $(2016$ 年 8 月 31 日開催). [http://www.rm-3prc.jp/ wordpress/board (accessed 2017-5-4)]

28）RevMate 第三者評価委員会. 第 24 回議事録 $(2016$ 年 11 月 30 日開催). [http://www.rm-3prc.jp/ wordpress/board (accessed 2017-5-4)]

29) RevMate 第三者評価委員会. 第 25 回議事録 $(2017$ 年 2 月 22 日開催)。 [http://www.rm-3prc.jp/ wordpress/board (accessed 2017-6-3) ]

30）厚生労働省医薬・生活衛生局安全対策課. 平成 28 年度第 10 回薬事. 食品衛生審議会医薬品等安全対 策部会安全対策調査会（2017 年 1 月 24 日開催）議 事 録. [http://www. mhlw. go.jp/stf/shingi2/ 0000153218.html (accessed 2017-6-3)] 
Special Issue on "Evaluation of Risk Minimization Plan"

\title{
2. Points for Evaluation of the Revised Risk Minimization Plans on Thalidomide and its Derivatives
}

\author{
Tsugumichi SATO
}

Faculty of Pharmaceutical Sciences, Tokyo University of Science/Ishizue Foundation

\section{$\langle$ Abstract〉}

Thalidomide and the derivatives, lenalidomide and pomalidomide, are the most potent teratogenic medicines. Thalidomide Education and Risk Management System $\left(\right.$ TERMS $^{\circledR}$ ) and RevMate ${ }^{\circledR}$ for lenalidomide and pomalidomide have been operated with a goal of no exposed embryo to the drugs. The TERMS $^{\circledR}$ and the RevMate ${ }^{\circledR}$, a centralized management system, were revised in 2016 according to a request by a patient group. After the revision, the patient self-check sheet on adherence to conception prevention is primarily confirmed by his/her doctor, and the content of the completed sheet is sent to the management center in the pharmaceutical company after dispensing of the drug. The points for evaluation of the revised system will be as follows. (1) Has an appropriate procedure in accordance with the revised system been established in respective hospitals? (2) The rate of non-compliance with the procedure by the doctors or pharmacists, (3) Effect on awareness and behavior of the patients. Questionnaire studies of the patients, doctors, and pharmacists have been performed by the third-party committees.

(Jpn J Pharmacoepidemiol 2017; 22 (1): 9-18)

Keywords: thalidomide, lenalidomide, pomalidomide, teratogens, risk management 